\title{
Bibliographical Abbreviations
}

$\begin{array}{ll}\text { A1 } & \text { Text edited in Abraham 2005/2006 } \\ \text { A2 } & \text { Text edited in Abraham 2007 } \\ \text { ABC } & \text { Grayson 1975a } \\ \text { ABS } & \text { Archaeology and Biblical Studies } \\ \text { AfO } & \text { Archiv fü Orientforschung } \\ \text { AIL } & \text { Ancient Israel and Its Literature } \\ \text { ANEM } & \text { Ancient Near East Monographs } \\ \text { AOAT } & \text { Alter Orient und Altes Testament } \\ \text { AoF } & \text { Altorientalische Forschungen } \\ \text { B } & \text { Texts edited in Wunsch (forthcoming) } \\ \text { BaAr } & \text { Babylonische Archive } \\ \text { BASOR } & \text { Bulletin of the American Schools of Oriental Research } \\ \text { BE } 8 & \text { Clay 1908 } \\ \text { BE 9 } & \text { Hilprecht and Clay 1898 } \\ \text { BE 10 } & \text { Clay 1904 } \\ \text { BIN 1 } & \text { Keiser, Clarence Elwood. Letters and Contracts from Erech Written } \\ & \text { in the Neo-Babylonian Period. Babylonian Inscriptions in the Col- } \\ \text { BiOr } & \text { lection of James B. Nies 1. New Haven: Yale University Press, 1918. } \\ \text { BM } & \text { Bibliotheca Orientalis } \\ \text { BMA } & \text { Tablets in the collections of the British Museum } \\ \text { BN } & \text { Texts edited in Roth 1989 } \\ \text { BSA } & \text { Biblische Notizen } \\ \text { BZAw } & \text { Bulletin on Sumerian Agriculture } \\ \text { C } & \text { Beihefte zur Zeitschrift für die alttestamentliche Wissenschaft } \\ \text { CAD } & \text { Texts edited in Pearce and Wunsch 2014 } \\ & \text { The Assyrian Dictionary of the Oriental Institute of the University of } \\ \text { Chicago. Chicago: The Oriental Institute of the University of Chi- } \\ \text { cago, 1956-2011. } \\ \text { Strassmaier, JN. Inschiften von Cambyses, Konig von Babylon. }\end{array}$

Camb Strassmaier, J.N. Inschriften von Cambyses, König von Babylon. Babylonische Texte Ix. Leipzig: Eduard Pfeiffer, 1890.

CatBM Catalogue of the Babylonian Tablets in the British Museum

CHANE Culture and History of the Ancient Near East

CLeO Classica et Orientalia

CM Cuneiform Monographs

CT 4 Pinches, T.G. Cuneiform Texts from Babylonian Tablets in the British Museum 4. London: The British Museum, 1898.

CT 55-57 Pinches, T.G. Cuneiform Texts from Babylonian Tablets in the British Museum, vols. 55-57. London: The British Museum, 1982. 
CTIJ Cuneiform Texts Mentioning Israelites, Judeans, and Related Population Groups (http://oracc.museum.upenn.edu/ctij/corpus)

CTMMA 4 Texts edited in Spar and Jursa 2014

Cyr Strassmaier, J.N. Inschriften von Cyrus, König von Babylon. Babylonische Texte VII. Leipzig: Eduard Pfeiffer, 1890.

Dar Strassmaier, J.N. Inschriften von Darius, König von Babylon. Babylonische Texte X-XII. Leipzig: Eduard Pfeiffer, 1892-1897.

EE $\quad$ Texts edited in Stolper 1985

GAG von Soden, Wolfram. Grundriss der akkadischen Grammatik samt Ergänzungsheft zum Grundriss der akkadischen Grammatik. Analecta Orientalia 33/47. Rome: Pontificium Institutum Biblicum, 1969 .

GMTR Guides to the Mesopotamian Textual Record

HdO Handbook of Oriental Studies, Section 1: The Near and Middle East

HSM Tablets in the collections of the Harvard Semitic Museum

IMT Texts edited in Donbaz and Stolper 1997

ISCANEE International Scholars Conference on Ancient Near Eastern Economies

J1-7 Texts edited in Joannès and Lemaire 1996

J8-9 Texts edited in Joannès and Lemaire 1999

JANEH Journal of Ancient Near Eastern History

JAOS Journal of the American Oriental Society

$J B L \quad$ Journal of Biblical Literature

JCs Journal of Cuneiform Studies

JESHO Journal of the Economic and Social History of the Orient

JNES Journal of Near Eastern Studies

JSJ Journal for the Study of Judaism

Jsots Journal for the Study of the Old Testament Supplement Series

KAI Texts edited in Donner and Röllig 2002

KTU Dietrich, Manfred et al. The Cuneiform Alphabetic Texts from Ugarit, Ras Ibn Hani and Other Places. Second, enlarged edition. Abhandlungen zur Literatur Alt-Syrien-Palästinas und Mesopotamiens 8. Münster: Ugarit-Verlag, 1995 .

LAOS Leipziger Altorientalistische Studien

MR Texts edited in Waerzeggers 2014a

NABU Nouvelles Assyriologiques Bréves et Utilitaires

Nbk Strassmaier, J.N. Inschriften von Nabuchodonosor, König von Babylon. Babylonische Texte V-VI. Leipzig: Eduard Pfeiffer, 1889.

Nbn Strassmaier, J.N.Inschriften von Nabonidus, Königvon Babylon. Babylonische Texte I-IV. Leipzig: Eduard Pfeiffer, 1889.

ND Field numbers of tablets excavated at Nimrud 
oect 10 McEwan, G.J.P. Late Babylonian Texts in the Ashmolean Museum. Oxford Editions of Cuneiform Texts 10. Oxford: Clarendon, 1984.

OIP 122 Weisberg, David B. Neo-Babylonian Texts in the Oriental Institute Collection. Oriental Institute Publications 122. Chicago: The Oriental Institute of the University of Chicago, 2003.

OIs Oriental Institute Seminars

OLA Orientalia Lovaniensia Analecta

PIHANS Uitgaven van het Nederlands Historisch-Archaeologisch Instituut te Istanbul = Uitgaven van het Nederlands Instituut voor het Nabije Oosten te Leiden

PBS 2/1 Clay 1912

PNA The Prosopography of the Neo-Assyrian Empire. Helsinki: The NeoAssyrian Text Corpus Project, 1998-.

$R A \quad$ Revue d'assyriologie et d'archéologie orientale

RINAP 1 Tadmor, Hayim and Yamada, Shigeo. The Royal Inscriptions of Tiglath-pileser III (744-727 BC), and Shalmaneser $V(726-722$ BC), Kings of Assyria. The Royal Inscriptions of the Neo-Assyrian Period 1. Winona Lake: Eisenbrauns, 2011.

RINAP 3 Grayson, A. Kirk and Novotny, Jamie. The Royal Inscriptions of Sennacherib, King of Assyria (704-681 BC), vols. 1-2. The Royal Inscriptions of the Neo-Assyrian Period 3. Winona Lake: Eisenbrauns, 2012-2014.

RINAP 4 Leichty, Erle. The Royal Inscriptions of Esarhaddon, King of Assyria $(680-669$ B $)$. The Royal Inscriptions of the Neo-Assyrian Period 4. Winona Lake: Eisenbrauns, 2011.

RlA Reallexikon der Assyriologie und Vorderasiatischen Archäologie. Berlin: De Gruyter, 1928-2018.

Rомст 2 McEwan, G.J.P. The Late Babylonian Tablets in the Royal Ontario Museum. Royal Ontario Museum Cuneiform Texts 2. Toronto: Royal Ontario Museum, 1982.

SAA 1 Parpola, Simo. The Correspondence of Sargon II, Part I: Letters from Assyria and the West. State Archives of Assyria 1. Helsinki: Helsinki University Press, 1987.

SAA 6 Kwasman, Theodore and Parpola, Simo. Legal Transactions of the Royal Court of Nineveh, Part I: Tiglath-pileser III through Esarhaddon. State Archives of Assyria 6. Helsinki: Helsinki University Press, 1991.

SAA 7 Fales, F.M. and Postgate, J.N. Imperial Administative Records, Part I: Palace and Temple Administration. State Archives of Assyria 7. Helsinki: Helsinki University Press, 1992. 
$S A A B \quad$ State Archives of Assyria Bulletin

SAOC Studies in Ancient Oriental Civilization

SCT Gordon, Cyrus H. Smith College Tablets: 110 Cuneiform Texts Selected from the College Collection. Smith College Studies in History 38. Northampton: Department of History of Smith College, $195^{2}$.

TA Tel Aviv

TAD A Porten, Bezalel and Yardeni, Ada. Textbook of Aramaic Documents from Ancient Egypt, vol. 1: Letters. Jerusalem: Hebrew University, 1986.

TCL 13 Contenau, G. Contrats néo-babyloniens, vol. 2: Achéménides et Séleucides. Textes cunéiformes, Musée du Louvre 13. Paris: Geuthner, 1929 .

TSAJ Texts and Studies in Ancient Judaism

TuM 2-3 Texts edited in Krückmann 1933

UCP 9/3 Text edited in Lutz 1928

UF Ugarit-Forschungen

van Driel, Working notes and transliterations of the Murašû texts by Govert working van Driel and his students, archived at Leiden University notes

VS 3-6 Ungnad, Arthur. Vorderasiatische Schriftdenkmäler der königlichen Museen zu Berlin, vols. 3-6. Leipzig: Hinrichs, 1907-1908.

VT Vetus Testamentum

VTSup Supplements to Vetus Testamentum

WdO Die Welt des Orients

WZKM Wiener Zeitschrift für die Kunde des Morgenlandes

Yos 6 Dougherty, Raymond Philip. Records from Erech, Time of Nabonidus (555-538 B.c.). Yale Oriental Series, Babylonian Texts 6. New Haven: Yale University Press, 1920.

Yos 19 Beaulieu, Paul-Alain. Legal and Administrative Texts from the Reign of Nabonidus. Yale Oriental Series, Babylonian Texts 19. New Haven: Yale University Press, 2000.

ZA Zeitschrift für Assyriologie und Vorderasiatische Archäologie

ZAW Zeitschrift für die alttestamentliche Wissenschaft

ZDMG Zeitschrift der Deutschen Morgenländischen Gesellschaft 